AJEB

7,1

Received 25 June 2020

Revised 1 October 2020

Accepted 14 October 2020

\section{Corporate board structures and intellectual capital: evidence from banks in Africa}

\author{
Nicholas Asare \\ Department of Accounting, University of Ghana Business School, Accra, Ghana and \\ Department of Accounting and Finance, School of Business, \\ Kwame Nkrumah University of Science and Technology, Kumasi, Ghana, and \\ Francis Aboagye-Otchere and Joseph Mensah Onumah \\ Department of Accounting, University of Ghana Business School, Accra, Ghana
}

\begin{abstract}
Purpose - This study examines the nature of the relationship between board structures (BSs) and intellectual capital (IC) of banks in Africa.

Design/methodology/approach - Using annual data from financial statements of 366 banks from 26 African countries from 2007 to 2015, the study estimates IC using the value-added intellectual coefficient (VAIC) and BSs using board size, board independence and board gender diversity. The system generalized method of moments and panel-corrected standard error estimation strategies are used to estimate panel regressions.

Findings - There is a significant negative relationship between board independence and intellectual capital. The results also indicate that the IC of banks does not depend on board size and board gender diversity.

Practical implications - The study's findings provide evidence of the extent to which BSs have been instituted to support investments in intellectual capital as a means of improving the performance of banks in Africa.

Originality/value - This study provides some empirical evidence from Africa's banking sector to justify that banks with better IC have boards that are less independent. This study is one of the few studies that employs many countries' data.
\end{abstract}

Keywords Corporate governance, Intellectual capital, Board structures, Banks, Africa

Paper type Research paper

\section{Introduction}

Good corporate governance (CG) and intellectual capital (IC) have been progressively documented as some of the main drivers of economic growth and development in contemporary times. As argued by Kaplan and Norton (2004), some high natural resource-endowed countries, such as Saudi Arabia and Venezuela as at then, made poor investments in their CG and IC. Consequently, they experienced many sluggish growths as their output per person was far less than countries like Taiwan and Singapore that had limited natural resources but invested profoundly in CG and IC (Kaplan and Norton, 2004). This argument could be juxtaposed to many African countries which have relatively lower investments in CG and IC.

The specific CG structures in the financial sector of an economy have substantial effects on the allocation of resources in the sector and the economy at large. At the firm level, one

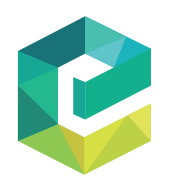

Asian Journal of Economics and Banking

Vol. 7 No. 1, 2023

pp. 146-163

Emerald Publishing Limited

e-ISSN: 2633-7991

p-ISSN: 2615-9821

DOI 10.1108/AJEB-06-2020-0020
(C) Nicholas Asare, Francis Aboagye-Otchere and Joseph Mensah Onumah. Published in Asian Journal of Economics and Banking. Published by Emerald Publishing Limited. This article is published under the Creative Commons Attribution (CC BY 4.0) licence. Anyone may reproduce, distribute, translate and create derivative works of this article (for both commercial and non-commercial purposes), subject to full attribution to the original publication and authors. The full terms of this licence may be seen at http://creativecommons.org/licences/by/4.0/legalcode.

The authors thank Gifty Asare of the University of Professional Studies Accra, Ghana and Audrey Gyamfi of Text Next Ltd for proof reading earlier versions of this paper. The authors bear the responsibility for any shortcomings. 
important detail of $\mathrm{CG}$ is the responsibilities and nature of the directors on corporate boards (Abor and Fiador, 2013). For instance, the size of a corporate board is relevant; and in line with the resource-based view theory, boards that are large, in most instances include a number of persons with diverse expertise, assorted educational backgrounds, abilities and skills that boost boards' proficiencies (Al-Musalli and Ismail, 2012). It is also recognized that the effectiveness of the board can be connected to the complementarity of non-executive and executive directors, gender of the directors (male and female), amongst others (Pearce and Zhara, 1992; Fama and Jensen, 1983). Overall, well-governed firms are likely to have higher performance in the financial sector (Kyereboah-Coleman and Biekpe, 2006).

In that regard, a firm's board of directors influence the nature of its IC investments and performance. At present, there is little agreement, if any, concerning the nature and strength of the relationship between CG structures and IC; and it is clear that this issue is a fruitful area of inquiry. For instance, the literature on the consequence of board structures (BSs) as an aspect of CG structures on firms' IC in the economic environment is inconclusive even though there is prevalent belief that good CG practices lead to superior IC (e.g. Nkundabanyanga, 2016; Al-Musalli and Ismail, 2012; Li et al., 2008; Cerbioni and Parbonetti, 2007; Swartz and Firer, 2005). Li et al. (2012) and Hidalgo et al. (2011) have mixed findings on the nature of the same relationship.

Africa as a veritable area for research has emerging banking markets that can help understand the nature of these relationships. The effects of BSs on IC could thus underlie the growth and development of the banking sector and thereby improve the efficiency of the African economy. The literature on CG in Africa is not too comprehensive (Aboagye and Otieku, 2010). Most empirical studies on CG and IC of firms have concentrated on non-African firms (Abor and Fiador, 2013; Asare et al., 2013, 2020; Wagiciengo and Belal, 2012; Kamath, 2008). Considering that $C G$ and institutions in most countries and regions function differently, it is imperative to also appreciate other perspectives of the issues from Africa (Duho, 2020; Abor and Fiador, 2013) though the literature on the particular relationship between BSs and IC even in developed countries appears to be scanty. Besides, this study is the first to combine bank data from many countries to understand issues of IC in the banking sector. This study is different from previous studies that concentrated on relatively small sample sizes in sectors other than the banking sector.

Makki et al. (2008) and Kalim and Lodhi (2002) using Pakistan as a case in point cautioned developing economies to initiate drastic steps to make their banking sectors extra IC resourceful; if not, they may drop even their current share of global exports. The banking sectors in most developing economies are perceived to be relatively characterized by low levels of competition and inefficiencies reflecting in high banking transactions and services costs. As a result, improving the banking sector's competitiveness, efficiency and performance in Africa necessitates actual empirical understanding about the effects of BSs on IC. The results of the study indicate that there is a significant negative relationship between IC and board independence. For banks to have better IC, their boards should be dominated by executive directors. The results also indicate that the IC of banks does not strongly depend on board size and board gender diversity. Larger bank boards or higher gender-diverse bank boards do not necessarily affect the IC of banks.

The remainder of this paper is structured in this manner. The following section provides a literature review on CG and IC. The section three is on data and methods. Empirical results are presented in section four with conclusions given in the last section.

\section{Review of literature}

Management of firms formulates policies and strategies to acquire, deploy and account for resources in the interest of their stakeholders (Asare, 2018). The ability to adhere to pre- 
AJEB

7,1

148

determined guidelines in CG has implications for IC management and accounting. Firms need to know what their competitive advantages are and what competencies they need to cultivate to preserve these advantages (Marr et al., 2004). Competencies are supported by knowledge; firms that seek to develop their competencies need to identify and manage their intangible assets, i.e. IC (Marr et al., 2004). These assets have been noted to contribute to firm performance and allow for accretion of wealth (Duho, 2020) in line with the resourcebased view.

In keeping with the resource-based view, an imperative function of a corporate board is the provision of resources and is directly linked to firm performance (Al-Musalli and Ismail, 2012; Pfeffer, 1972). The corporate BSs tend to affect the resourcefulness of bank boards in discharging their legitimate duties. The size of a corporate board is important and larger boards in most instances include a number of individuals with diverse expertise, assorted educational and professional backgrounds, abilities and skills that boost boards' proficiencies (Kusi et al., 2018; Al-Musalli and Ismail, 2012). The largeness of a bank board's size in that regard will positively increase the financial performance of the bank. Also, the variety that comes with board diversity, such as the different expertise and managerial backgrounds, personalities, learning styles, gender, ages, race, education, values etc. (Williams, 2000), is likely to result in the efficient management of IC and performance.

The resource-based view perspective thus offers insights into how attaining control of critical IC resources delivers better bank performance, and how developing resource interdependencies around critical resources affect the performance derived from them (Asare et al., 2020; Nkundabanyanga, 2016). Studies find positive relations between BSs as a component of CG and IC (see Daryaee et al.,2011; Li et al., 2008; Cerbioni and Parbonetti, 2007; Swartz and Firer, 2005). Makki and Lodhi (2009) also reveal and determine the existence of a critical structural relationship between CG and IC. BSs are critical to decisions concerning resources, including IC. Specifically, Habib (2015) finds a positive relationship between the number of directors, i.e. board size and effective monitoring of managerial behaviour, which contributes to improvement in financial performance. Williams et al. (2005) maintain that a bigger board size has more specialized skills and is better equipped to monitor management. Moreover, it is maintained that larger boards are more likely to increase firms' ability to obtain and secure critical resources from their environment, such as IC (Abeysekera, 2010), thus supporting improved relational capital in the firms' dealings with stakeholders. More explicitly, Al-Musalli and Ismail (2012) and Joshi et al. (2010) find that board size has no significant relationship with IC of banks in Arab Gulf Cooperation Council regions and Australian owned banks. Based on these mixed findings, the current study also seeks to understand the nature of the same relationship using many countries and several banks' data. This may offer robust findings on the relationship between the variables.

Additionally, a corporate board is seen to be more independent if it has more nonexecutive directors (John and Senbet, 1998). It is commonly acknowledged that the effective performance of the board depends on having the right proportion of executive and nonexecutive directors on the board (Pearce and Zhara, 1992; Fama and Jensen, 1983). Theory submits that non-executive directors often have less information about the business of the firm and have difficulty understanding the complexities of the firm (Weir and Laing, 2000). It can be argued that, executive directors are more familiar with the activities of the firm and are therefore in a better position to monitor top management. In contrast, a high proportion of outside directors on a board provide healthier settings for making quality shared decisions (Kusi et al., 2018; Fama and Jensen, 1983). Hermalin and Weisbach (2003) put forward that there is little to suggest that board composition has any cross-sectional relation with firm value. In other words, boards that have independent non-executive directors are stronger in monitoring and evaluation, and this can improve IC. Nonetheless, the extent to which this could reflect in banks' IC is not clear in the literature. Al-Musalli and Ismail (2012) and 
Mujtaba and Williams (2011)'s findings show that the number of independent directors on firm boards have a significant negative relationship with IC.

Also, the diversity of corporate boards is a topical issue in CG. It has been looked at from several perspectives such as gender, ethnicity and professional background in many areas of management research (Asare, 2018). Prior literature on gender diversity in teams of decisionmakers indicates that diversity could either improve the quality of decisions by bringing in new viewpoints and enriching the information set accessible to the team or could obstruct effective team performance by increasing disagreement and conflicts (Boone and Hendriks, 2009; Mannix and Neale, 2005). Kyereboah-Coleman (2006) finds that board diversity through the inclusion of women is important for the enhanced performance of firms. Kusi et al. (2018) find similar results as Kyereboah-Coleman (2006) and thus clearly illustrate that genderdiverse boards are likely to be resourceful in decision-making. In addition, Swartz and Firer's (2005) empirical results indicated a positive significant relationship between the percentage of ethnic members on a firm's board and IC. Swartz and Firer (2005) did not consider gender diversity of the boards of the firms used in their study. Based on the limited literature and the resource-based view, more diverse bank boards are likely to have higher IC performance.

On the basis of the literature reviewed, this study hypothesizes that:

H1. Board size has a positive relationship with IC.

H2. Board independence has a positive relationship with IC.

H3. Board gender diversity has a positive relationship with IC.

\section{Methods and data}

The data from the unconsolidated financial statements of banks were sourced from the Bankscope database in August 2018; data covers financial statements, from 2007 to 2015 of banks in various countries in Africa (see Appendix 1; Asare, 2018). The sample includes commercial, development, mortgage, savings and co-operative banks. Country-specific data on macroeconomic variables and governance were also obtained from the Global Financial Development Database (GFDD) of the World Bank and the World Development Indicators (WDIs) database (2016). The number of banks sampled, and the time interval used for the study were partly restricted by the availability of data and the authors' desire to contribute to the extant literature using a panel data approach. The variables measured and used in this study are enshrined and expatiated in Table 1.

\subsection{Specification of the model and estimation strategies}

Panel regression model (equation 1) is specified to assess the nature of the relationship between BSs and IC. It follows arguments put forward by Valverde and Fernaindez (2017) that banks maximize wealth by considering both opening and end-of-period information and that previous values of the value-added intellectual coefficient (VAIC) may affect present values.

$$
\begin{aligned}
\text { VAIC }_{i t}= & \lambda_{0}+\lambda_{1} \text { VAIC }_{i t-1}+\lambda_{2} \text { BODSIZE }_{i t}+\lambda_{3} \text { BODIND }_{i t}+\lambda_{4} \text { BODGEN }_{i t}+\lambda_{5} \text { BSIZE }_{i t} \\
& +\lambda_{6} \text { CRL5 }_{i t}+\lambda_{7} G D P_{i t}+\varepsilon_{i t}
\end{aligned}
$$

where, $V A I C_{i t}$ is the value-added intellectual coefficient, an IC measure of a bank $i$ in the time $t, V A I C_{i t-1}$ is one period lagged observations of the respective variables of a bank. BODSIZE is the board size of bank $i$ in time $t ; B O D I N D$ is board independence of bank $I$ in time $t$; $B O D G E N$ is board gender diversity of bank $i$ in time $t, B S I Z E$ is bank size of bank $I$ in time $t$; CRL5 is 5 bank loan concentration ratio of the industry in time $t$; GDP is the gross domestic 
AJEB

\begin{tabular}{|c|c|c|c|c|}
\hline Variable & Acronym & $\begin{array}{l}\text { Operational definition and } \\
\text { sources }\end{array}$ & Pointer & Data source \\
\hline Intellectual capital & $\begin{array}{l}\mathrm{IC} \\
\left(\mathrm{VAIC}^{\mathrm{TM}}\right)\end{array}$ & $\begin{array}{l}\text { This study adopts the value- } \\
\text { added intellectual coefficient } \\
-\left(\text { VAIC }^{\mathrm{TM}}\right)^{\mathrm{a}} \text { as proposed by } \\
\text { Pulic }(2004,2008) \text { to measure }\end{array}$ & $\begin{array}{l}\text { Value creation } \\
\text { performance }\end{array}$ & $\begin{array}{l}\text { Bank annual } \\
\text { financial report - } \\
\text { Computations from } \\
\text { Bankscope }\end{array}$ \\
\hline
\end{tabular}

150

IC of the selected banks. The

VAIC has been widely used in the literature to measure IC (Chen et al., 2014; Goh, 2005). Further details on its computations is in Appendix 3 of this study

Board size

Board

independence/

Composition

Board diversity

Bank size

BSIZE

Banking market structure

CLR5

The number of directors

who serve on the board of a bank (Abeysekera, 2010;

Naimi et al., 2010)

BODIND The proportion of independent non-executive directors on the board; that is, the number of independent non-executive directors to the total number of directors on the board (Kusi et al., 2018; Duru et al., 2016)

$B O D G E N$ The proportion of directors on the board that is female; that is, the number of female directors to the total number of directors on the board (see Kusi et al., 2018; Duru et al., 2016)

A natural logarithm of the bank's fiscal year-end total assets (Asare et al., 2017; A1Ghanem and Hegazy, 2011)

The ratio of the total loan assets of the five largest banks to total industry loan assets (Alhassan and Asare, 2016; Al-Musalli and Ismail, 2012)

Gross domestic product per capita GDPpcg growth rate
GDP per capita growth is incorporated as justification for differences in macroeconomic environments of the countries (Asare, 2018). Growth rate of real GDP per capita
Good corporate Bank annual

Governance financial report Computations from Bankscope

Good corporate Bank annual Governance financial report Computations from Bankscope

Good corporate

Governance

Bank annual financial report Computations from Bankscope

Size

Bank annual financial report Computations from Bankscope

Market concentration

Bank annual financial report Computations from Bankscope

Macroeconomic

World development indicators-database published by World bank
Table 1.

Summary of the definitions of variables
Note(s): 'Greater value for the VAIC demonstrates a grander efficiency of the firms' resources in generating value (Pulic, 2008) 
product per capita growth rate of a country in time $t ; \lambda$ is the coefficient while $\varepsilon_{\text {it }}$ is the error term.

The basic models of this study are first estimated with the ordinary least squares (OLS)panel corrected standard errors (PCSEs) (see also Owusu et al., 2017). In justifying the application of the OLS-PCSE, the Wooldridge (2003) test of no first-order autocorrelation and Breusch-Pagan/Cook-Weisberg test are used to confirm the presence of serial correlation and heteroscedasticity (Bailey and Katz, 2011). The study employs the dynamic panel approach as the main estimation technique to deal with the shortcomings of the OLS-PCSE. The approach offers benefits over OLS and develops on prior efforts to examine the associations between CG and IC. The study uses the generalized methods of moments (GMM) estimator as propounded and developed by Arellano and Bover (1995) and Blundell and Bond (1998) for dynamic panel data. Owusu et al. (2017) and Wintoki et al. (2012) agree that the GMM estimator can effectually deal with the problem of unobserved heterogeneity. It permits for a dynamic relation of the dependent variable while also adjusting for endogeneity biases.

\section{The analysis of results}

\subsection{Descriptive statistics}

Table 2 shows the yearly averages of IC, i.e. VAIC. It can be realized that, the average VAIC of the banks is 2.3483. The average VAIC has decreased over the period (2.2844 in 2007 to 2.1658 in 2015). Kruskal-Wallis test undertaken to determine whether there are differences between the means of the VAIC over the years indicates a VAIC which is not statistically different across the years. The results demonstrate that the mean VAIC for banks is not essentially different over the years. A higher value for VAIC depicts a greater efficiency of IC in creating value for a firm (Pulic, 2008). This value is the minimum for efficient firm performance in the banking sector (i.e. sufficient value is being created to cover for employees' salaries, amortization, bank interests, taxes and dividends to shareholders) and enough is left for intensive investments in development (Pulic, 2008). Thus, on average, the value creation efficiency of African banks from the perspective of IC is quite low compared to banks/firms on other continents. The average VAIC of the banking sector in this study is lesser than the values reported by Ozkan et. al. (2017) in Turkey's banking sector (3.8868), El-Bannany (2008) for UK banks (10.80), Goh (2005) for Malaysian banks (7.11), Makki et al. (2008) for Pakistani listed corporate sector (7.60) and Joshi et al. (2010) in Australia (3.80). Abeysekera (2007) attributes these dissimilarities in the values and practices to economic, social and political factors.

\begin{tabular}{lc}
\hline Year & VAIC \\
\hline 2007 & 2.2844 \\
2008 & 2.6624 \\
2009 & 2.3131 \\
2010 & 2.3677 \\
2011 & 2.4904 \\
2012 & 2.1905 \\
2013 & 2.2646 \\
2014 & 2.3619 \\
2015 & 2.1658 \\
Overall average & 2.3483 \\
Kruskal-Wallis $\chi^{2}$ & 7.952
\end{tabular}

Note(s): The VAIC is the IC performance

Source(s): Authors' computations from data from Bank Scope, 2019

Table 2.

Yearly intellectual capital performance 
AJEB

7,1

152

From Table 3, the average board size (BODSIZE) for a bank in Africa is 9.0894 members. This is in tandem with findings of Aboagye-Otchere (2014), Naimi et al. (2010) and Yatim et al. (2006) who obtained an average board size of 8/9 directors for firms. Regarding the proportion of independent non-executive directors that make up the board, i.e. board independence $(B O D I N D)$, the descriptive statistics reveal that for the entire duration of the study, it is 0.1549 , indicating that about $16 \%$ of directors on the boards are nonexecutive directors. This result is lower than that which was obtained by Aboagye-Otchere (2014), Yaacob and CheAhmad (2012) and Mohamad-Nor et al. (2010), which were 69, 40 and 43\%, respectively, in firms. Interestingly, it can be deduced that the proportion of nonexecutive directors on the board of banks is increasing. This means that the banking sector in Africa is gradually incorporating the notion of independent nonexecutive directors. It was 0.6167 in 2015 as against 0.1521 in 2007. There was a significant change between 2013 and 2014. Therefore, in 2015 the majority of board members of banks were nonexecutive directors. On the other hand, the average ratio for board gender diversity (BODGEN) of the banks is 0.1076 ( 0.1074 in 2007 to 0.0834 in 2015). This indicates that about $11 \%$ of board members of a bank in Africa are women and that there has been no improvement in the number of women on the boards of banks over the period via affirmative actions. Also, the results from the Kruskal-Wallis test suggest that there is no statistically significant difference in the average scores of the BS variables over the years. The results thus show that average BODSIZE, BODIND and $B O D G E N$ for the years are not significantly higher or lower than each other.

Results in Table 4 also indicate an average bank size (BSIZE) of 4.3482 over the period. It could be deduced that banks in Africa are relatively small. The average 5-bank loan concentration (CRL5) of banks is $82.3796 \%$. This is greater than what Alhassan and Asare (2016) realized in the specific context of Ghana, i.e. $53.27 \%$. This indicates that about $82 \%$ of the loan portfolio of banks is controlled by the largest five banks in a specific country. In terms of the macro-economic indicators, the average gross domestic product per capita growth rate (GDPpcg) in Africa is $2.7578 \%$ with a standard deviation of 2.7873. Asare (2018) obtained similar average GDPpcg.

\subsection{Effects of corporate board structures on intellectual capital}

In keeping with Kennedy (2008) that multicollinearity exists when the correlation coefficients between any two (2) variables is greater than 0.70 , the results presented in Table 5 show that using all the independent and control variables in the regression does not result in any

\begin{tabular}{lccc}
\hline Year & BODSIZE & BODIND & BODGEN \\
\hline 2007 & 9.1181 & 0.1521 & 0.1074 \\
2008 & 9.0655 & 0.1547 & 0.1078 \\
2009 & 9.1000 & 0.1547 & 0.1087 \\
2010 & 9.1069 & 0.1536 & 0.1075 \\
2011 & 9.1031 & 0.1544 & 0.1076 \\
2012 & 9.0925 & 0.1538 & 0.1072 \\
2013 & 9.0893 & 0.1544 & 0.1072 \\
2014 & 5.5000 & 0.6167 & 0.0834 \\
2015 & 5.5000 & 0.6167 & 0.0834 \\
Average & 9.0894 & 0.1549 & 0.1076 \\
Kruskal-Wallis $\chi^{2}$ & 1.162 & 7.473 & 0.035
\end{tabular}

Table 3.

Yearly board structures
Note(s): $B O D S I Z E$ is the board size; BODIND is board independence; $B O D G E N$ is board gender diversity

Source(s): Bank Scope and authors' computations, 2019 


\begin{tabular}{lrrrrr}
\hline & Obs. & Mean & Max & Min & SD \\
\hline VAIC & 2,450 & 2.3483 & 12.7358 & -8.4692 & 2.2987 \\
BODSIZE & 2036 & 9.0894 & 46.0000 & 1.0000 & 6.7847 \\
BODIND & 2036 & 0.1549 & 0.9000 & 0.0000 & 0.2478 \\
BODGEN & 2036 & 0.1076 & 1.0000 & 0.0000 & 0.1287 \\
BSIZE & 2,439 & 4.3482 & 7.2304 & 1.0828 & 1.1987 \\
CRL5 & 2,489 & 82.3796 & 100.0000 & 55.7144 & 13.6246 \\
GDPpcg & 2,052 & 2.7578 & 12.4243 & -7.9079 & 2.7873
\end{tabular}

Board structures and intellectual capital 153

Note(s): VAIC is the IC performance; BODSIZE is the board size; BODIND is board independence; BODGEN is board gender diversity; BSIZE is bank size; CRL 5 is 5 bank loan concentration ratio; GDPpcg is gross domestic product per capita growth rate

Source(s): Bank Scope and authors' computations, 2019

Table 4. Summary statistics

multicollinearity, which could bias the model's coefficients. Strangely, BODSIZE is inversely related to BSIZE. It could be as a result of the lack of harmonization of CG practices across countries and banks in Africa. Corporate governance structures of banks are even noted to be in their nascent stages in parts of Africa (Abor and Fiador, 2013). As a robustness check on multicollinearity, the variance inflation factor (VIF) [1], as shown in Appendix 2, is calculated. The VIF shows a mean of 1.5500 and thus indicates that the VIF's mean is within acceptable levels. Hence, the test result endorses the result of the Spearman's test.

The panel regression analysis in Table 6 is used to establish the relationship between VAIC and BSs, i.e. BODSIZE, BODIND and BODGEN, controlling for other bank-specific and macro-economic variables, such as BSIZE, CRL5 and GDPpcg. Two estimation analyses, i.e. system GMM and OLS-PCSE, are applied. Concerning the OLS-PCSE model, the probability of the Wald chi-squared test of serial correlation [2] in this instance indicates the absence of no first-order autocorrelation. This is an attestation of the suitability of the model used in estimating the relationship between the variables. The study panel is unbalanced, and the total observations are 932 for 366 banks.

The results of the OLS-PCSE show that BODSIZE and BODIND have a negative relationship with VAIC, with $B O D G E N$ having a positive relationship with VAIC. This indicates that smaller BODSIZE, less BODIND and more BODGEN result in higher VAIC. However, the relationships between BODIND and BODGEN, on the one hand, and VAIC, on the other hand, are significant. This is an indication that the VAIC level of a bank does depend on the independence of the bank's board. As the bank's board becomes more independent, VAIC tends to be decreasing. This implies that the inclusion of fewer executive directors on bank boards does not bring to bear IC issues of the banks that ought to be given attention by the boards and as such does not help in the performance of IC. This finding is similar to findings of Al-Musalli and Ismail (2012) and Mujtaba and Williams' (2011) that board independence has a significant negative relationship with VAIC.

Al-Musalli and Ismail (2012) and Mujtaba and Williams (2011) state that the notion of independent directors is fairly new in the Arab Gulf Cooperation Council region, and there are challenges related with the appointment of suitable and rightly independent directors on the boards of firms in the region. Besides, Abor and Fiador (2013) give an indication that CG could be in its nascent stages in parts of Africa. This study concurs with Al-Musalli and Ismail (2012) and Mujtaba and Williams (2011) and thus states that similar challenges could account for the negative relationship between IC and the nature of the independence of the boards of the banks in Africa. From the descriptive statistics, only about $16 \%$ of board members of banks are independent directors, and this could be a reason for the results, as the boards do not have the required number of non-executive directors to make the necessary impact. 


\section{$\mathrm{AJEB}$ \\ 7,1}

\begin{tabular}{lccllll}
\hline & BODSIZE & BODIND & BODGEN & BSIZE & CRL5 & GDPpcg \\
\hline BODSIZE & 1.0000 & & & & & \\
BODIND & $0.2544^{* * *}$ & 1.0000 & & & & \\
BODGEN & $0.2953^{* * *}$ & $0.2143^{* * *}$ & 1.0000 & & & \\
BSIZE & $-0.0435^{*}$ & $-0.0552^{* * *}$ & $0.1083^{* * *}$ & 1.0000 & & \\
CRL5 & $0.1273^{* * *}$ & -0.0059 & $0.0520^{* *}$ & $0.1460^{* * *}$ & 1.0000 & \\
GDPpcg & 0.0292 & $0.1092^{* * *}$ & 0.0342 & $-0.1685^{* * *}$ & $-0.1613^{* * * *}$ & 1.0000
\end{tabular}

Table 5.

Spearman correlation matrix

Note(s): ***, ** and $*$ denote significance at 1,5 and $10 \%$, respectively

$B O D S I Z E$ is the board size; BODIND is board independence; BODGEN is board gender diversity; BSIZE is bank size; CRL 5 is 5 bank loan concentration ratio; GDPpcg is gross domestic product per capita growth rate Source(s): Bank Scope and authors' computations, 2019

\begin{tabular}{|c|c|c|}
\hline \multicolumn{3}{|c|}{$\begin{array}{c}\text { Dependent variable: Value-added intellectual coefficient } \\
\text { OLS-PCSE }\end{array}$} \\
\hline $\begin{array}{l}\text { Lag } \\
\text { BODSIZE } \\
\text { BODIND } \\
\text { BODGEN } \\
\text { BSIZE } \\
\text { CRL5 } \\
\text { GDPpcg } \\
\text { Constant }\end{array}$ & $\begin{array}{c}-0.0070(-0.9000) \\
-0.5951 * *(-2.0900) \\
0.7985 *(1.7500) \\
-0.2052^{* * * *}(-3.9100) \\
0.0005(0.1100) \\
0.0204(0.9700) \\
2.1858 * * *(5.0700)\end{array}$ & $\begin{array}{c}0.2459 * * *(3.0700) \\
1.1125(0.5600) \\
-2.7029 *(-0.1100) \\
-45.3399(-0.5400) \\
-1.4003(-1.1700) \\
0.0122(0.1300) \\
0.1400(1.0200) \\
1.2642(0.1300)\end{array}$ \\
\hline $\begin{array}{l}\text { Diagnostics } \\
R \text {-squared } \\
\text { Number of Groups } \\
\text { Number of instruments } \\
\text { Observations } \\
\text { Wald } \chi^{2}(6) \\
F \text {-test } \\
\text { AR(1) } \\
p \text {-value } \\
\text { AR(2) } \\
p \text {-value } \\
\text { Hansen J } \\
p \text {-value }\end{array}$ & $\begin{array}{c}0.2112 \\
255.0000 \\
\\
932.0000 \\
148.6400^{* * *}\end{array}$ & $\begin{array}{c}255.0000 \\
14.0000 \\
932.0000 \\
\\
2.9400 * * * \\
-4.9200 \\
0.0000 \\
0.9800 \\
0.3250 \\
3.1100 \\
0.7950\end{array}$ \\
\hline \multicolumn{3}{|c|}{$\begin{array}{l}\text { Note(s): } * * *, * * \text { and } * \text { denote significance levels of } 1,5 \text { and } 10 \% \text {, respectively. Where VAIC is the IC } \\
\text { performance; } B O D S I Z E \text { is the board size; BODIND is board independence; } B O D G E N \text { is board gender diversity; } \\
B S I Z E \text { is bank size; } C R L 5 \text { is } 5 \text { bank loan concentration ratio; GDPpcg is gross domestic product per capita } \\
\text { growth rate. Numbers in parentheses are } z \text {-statistics and } t \text {-statistics respectively } \\
\text { Source(s): Bank Scope and authors' computations, } 2019\end{array}$} \\
\hline
\end{tabular}

Table 6.

Board structures and intellectual capital
Accordingly, it appears that the independent directors only sit on boards to satisfy the requirements of codes of CG but might not be able to exercise their powers (Al-Musalli and Ismail, 2012). It could also be generally accepted that there is no right proportion of executive and non-executive directors on the boards, and as such, there is no effective performance of the board to influence IC (Fama and Jensen, 1983; Pearce and Zhara, 1992). This again confirms the view of Weir and Laing (2000) that non-executive directors often have less information about the business of the firm and have difficulty understanding the complexities of the firm. 
The results also indicate that a higher VAIC of a bank does not depend on the size of the board as there is no significant relationship between the two variables. In other words, banks that have larger boards are also noted not to necessarily have higher VAIC. The board size does not predict the level of VAIC of banks. Hence, it cannot be concluded that banks with larger boards have a higher performance of IC. This result counters Al-Musalli and Ismail's (2012) and Joshi et al.'s (2010) findings. This is contrary to the view that larger boards are more likely to increase firms' ability to obtain and secure critical resources from their environment, such as IC (Abeysekera, 2010). This also does not support the resource-based view. The resource-based view indicates that firms gain competitive advantage and superior performance via the acquisition, holding and subsequent usage of strategic IC (see Barney, 1991; Wernerfelt, 1984). The resource-based view also indicates that an imperative function of the bank board is the provision of IC to improve bank performance (Al-Musalli and Ismail, 2012; Pfeffer, 1972). The reason for the nonexistence of any relationship between board size and IC cannot be the fact that the board size in African banks is abnormal as the study finds the average size of a board to be 9.0894 members and is similar to that found in other jurisdictions by Naimi et al. (2010) and Yatim et al. (2006).

Also, a BS in the form of board diversity is seen to have a significant positive relationship with VAIC. Banks that have boards that are gender-diverse tend to have higher IC. This result is similar to Swartz and Firer (2005) that indicated a positive relationship between board diversity and IC. This evidence also supports the resource-based view that boards that are diverse in terms of gender are likely to have a pool of feminine expertise that could propel different ideas to improve board functions and the quality of decisions by bringing in new perspectives and enriching the information set available to the team, such as managing IC investments (Boone and Hendriks, 2009; Mannix and Neale, 2005).

In terms of the control variables, BSIZE is negatively related to VAIC significantly; i.e. larger banks have lower VAIC. This is contrary to Alhassan and Asare (2016), Al-Musalli and Ismail (2012) and Youndt et al. (2004) but similar to Goebel (2015). This indicates that large banks are not efficient with the utilization of IC than small banks, and this does not reflect the economies of scale and scope enjoyed by large banks. This means that the size of banks influences their value creation efficiency (Asare, 2018). Smaller banks have better IC investments and utilize them to create diverse value for stakeholders. Unexpectedly, the GDPpcg of the operating environment of a bank does not contribute to its value creation abilities. The economic growth i.e. GDPpcg perhaps affects the value-creating efficiency of the banks not from an IC perspective. Perhaps, the banks are rather contributing to the economic growth of the countries they are operating in and as such could account for the relationship indicated.

The OLS estimation fails to justify the probability of preceding VAIC affecting current VAIC. The system GMM estimation comes in to also deal with endogeneity concerns that are inherent in the models estimated by the OLS-PCSE. The validity and robustness of the system GMM are tested with Hansen J and Arellano-Bond tests. They make available sufficient proof of the dependability of the estimated coefficients in the models. The Hansen J tests the null hypothesis that the over-identifying constraints are valid. The test outcomes for the models do not reject the null hypothesis of valid instruments. Though the models depict no first-order autocorrelation, the null hypothesis of no second-order auto-correlation could not also be rejected (Arellano and Bond, 1991).

As a justification for using the system GMM, the regression indicates that the lag of the VAIC influences VAIC positively and thus points out that the previous year's IC of a bank affects its current IC. With the exception of BODSIZE that has a positive relationship with VAIC, the BS variables have a negative relationship with VAIC. The results of the system GMM show that BODIND has a negative and significant relationship with VAIC. This is similar to the OLS-PCSE results obtained in this section. The alternate hypothesis H2 that structures and intellectual capital 
AJEB

7,1

156

there is a positive relationship between $B O D I N D$ and IC is thus rejected. It is again similar to Al-Musalli and Ismail (2012) and Mujtaba and Williams (2011). As already indicated, the VAIC level of banks does depend on the independence of the banks' boards.

The system GMM results also do not find any strong positive association between the size of the board (BODSIZE) and VAIC in the banking sector of Africa. In other words, banks that have smaller boards are also noted to have lower IC. The coefficient for the BODSIZE is not significant, indicating a weak association. This accepts the $H_{\mathrm{o}}$ that there is no positive relationship between board size and IC. This result is contradictory to the findings of the OLSPCSE but similar to that of Al-Musalli and Ismail (2012). In terms of board size, it is also an indication that there is no evidence to support the resource-based view in the context of the banking sector in Africa. With respect to BODGEN, the system GMM estimations find no evidence to support the OLS-PCSE. The results here indicate no significant relationship between BODGEN and VAIC, which is contrary to Swartz and Firer (2005). Hypothesis H3 which states that there is a positive relationship between the diversity of the board and the IC of banks is rejected.

In terms of the control variables, none depicted a strong association with VAIC in the system GMM estimation. The OLS-PCSE and system GMM show that BSIZE is negatively related to VAIC but not significantly. Like in the OLS-PCSE, the results in the system GMM also indicate that the CRL5 and GDPpcg GMM have positive and insignificant relations with VAIC. These indicate the inconsistency of results across the two estimations.

\section{Conclusion}

The study concludes that the composition of the boards, i.e. board independence of the banks thus has repercussions on investments in IC, which also has consequences on their value creation efficiencies. This is because the results of the study indicate that board independence has a significant negative relationship with IC. Thus, less independent boards tend to make policies and take actions that improve IC. The results also indicate that the IC of banks does not strongly depend on board size and board gender diversity. In other words, banks with larger boards or more gender-diverse boards are noted not to necessarily have higher IC.

Inferring from the findings of this study, as boards become less independent, they tend to make policies and take actions that advance IC, i.e. improvements in career development policies and programmes; recruitments of top management personnel, employees with requisite qualifications and employment profile; improvements in incentives and employee welfare issues; improvement of overall working conditions and culture; institution of improved information systems and internal controls; building networks of important stakeholders. Furthermore, bank boards with more executive directors are likely to support nobility in work environments; encourage good negotiating skills to clinch contracts and agreements with partners and clients; build a brand and reputation for the bank, etc. This evidence does not necessarily support the resource-based view that portends that independent bank boards are much resourceful. Enterprises from the regulatory bodies in relation to these are necessary periodically to make the banking sector robust in Africa. The central banks should continue to take actions toward instituting and developing bank BSs to influence bank IC investments and managements. The central banks should control board composition/independence as a BS to make bank management better in specific situations. Any attempt by central banks, other regulatory bodies and management of banks that emphasize on improving bank BS to supervise important investments and managements of IC could accelerate their growths. The study recommends that the executive directors should dominate boards of banks. Nevertheless, banks are cautioned to be circumspect in increasing their executive directors on the boards as the inclusion of the right proportion of executive 
and non-executive directors is equally important for accountability and transparency purposes.

Large bank boards with more executive and non-executive directors tend not to have any extreme impact on IC of banks. Larger boards do not necessarily have greater insights into the operation of the banks and are not inevitably able to institute measures that improve IC investments and managements thereby increasing value creation efficiencies. Banks with smaller boards do not have IC efficiencies that help them to gain more competitive advantages than their counterparts with larger boards. For better bank IC, bank board size should not be a factor.

The study also emphasizes that, boards dominated by more female directors are not likely to have better IC. Banks in Africa in general, should not increase the number of female directors on their boards as a way of improving their IC managements and performance. The acquisition, holding, management and reporting of IC in banks are seen as part of IC accounting and are based on governance decisions. The composition of boards with respect to male and female directors does not have many implications on IC investments and performance.

The study's data and methods are bound by some latent limitations. This study concentrated on secondary data sources and is prone to challenges of using such data for research analysis. Data for this study were collected for several countries. The political, social and economic systems differ across the countries and sub-regions used in this study and as such peculiarity of results are bound. The study is also limited to the financial sector and specifically, the banking industry in terms of its generalization. More studies, particularly in Africa, are necessary to corroborate this study's findings and contribute to the extant literature. The effect of other contextual CG variables, which were not considered in this study, could also be explored. It is also recommended that researchers interested in this area should investigate why some BS variables employed in this study did not have significant influence on IC through other quantitative/qualitative studies.

\section{Notes}

1. As a rule of thumb, if the VIF of a variable exceeds 10 (VIF $>10)$, it is considered to be highly collinear (Gujarati and Porter, 2003).

2. A probability of Wald chi-squared less than 0.05 indicates the fitness of the model in explaining the relationship between the independent and dependent variables.

\section{References}

Abeysekera, I. (2007), "Intellectual capital reporting between a developing and developed nation", Journal of Intellectual Capital, Vol. 8 No. 2, pp. 329-345.

Abeysekera, I. (2010), "The influence of board size on intellectual capital disclosure by Kenyan listed firms", Journal of Intellectual Capital, Vol. 11 No. 4, pp. 504-518.

Aboagye, A.Q. and Otieku, J. (2010), “Are Ghanaian MFIs' performance associated with corporate governance?", Corporate Governance: The International Journal of Business in Society, Vol. 10 No. 3, pp. 307-320.

Aboagye-Otchere, F. (2014), "International Financial Reporting Standards (IFRS), financial disclosure and corporate governance disclosure in Ghana", Unpublished $\mathrm{PhD}$ thesis, University of Ghana, Legon).

Abor, J. and Fiador, V. (2013), "Does corporate governance explain dividend policy in Sub-Saharan Africa?", International Journal of Law and Management, Vol. 55 No. 3, pp. 201-225.

Al-Ghanem, W. and Hegazy, M. (2011), "An empirical analysis of audit delays and timeliness of corporate financial reporting in Kuwait”, Eurasian Business Review, Vol. 1 No. 1, pp. 73-90. 
AJEB

7,1

158

Al-Musalli, M.A.K. and Ismail, K.N.I.K. (2012), "Corporate governance, bank specific characteristics, banking industry characteristics, and intellectual capital performance of banks in Arab Gulf Cooperation Council (GCC) Countries", Asian Academy of Management Journal of Accounting and Finance, Vol. 8, Supp. 1, pp. 115-135.

Alhassan, A.L. and Asare, N. (2016), "Intellectual capital and bank productivity in emerging markets: evidence from Ghana", Management Decision, Vol. 54 No. 3, pp. 589-609.

Arellano, M. and Bond, S. (1991), "Some tests of specification for panel data: Monte Carlo evidence and an application to employment equations", The Review of Economic Studies, Vol. 58 No. 2, pp. 277-297.

Arellano, M. and Bover, O. (1995), "Another look at the instrumental-variable estimation of errorcomponents", Journal of Economics, Vol. 68, pp. 29-52.

Asare, N. (2018), "An investigation into board structures, intellectual capital and performance of Banks in Africa", $\mathrm{PhD}$ thesis, University of Ghana, Ghana, ugspace.ug.edu.gh.

Asare, N., Onumah, J.M. and Simpson, S.N.Y. (2013), "Exploring the disclosure of intellectual capital in Ghana: evidence from listed companies", Journal of Accounting and Marketing, Vol. 2 No. 3, pp. 1-7.

Asare, N., Alhassan, A.L., Asamoah, M.E. and Ntow-Gyamfi, M. (2017), "Intellectual capital and profitability in an emerging insurance market", Journal of Economic and Administrative Sciences, Vol. 33 No. 1, pp. 2-19.

Asare, N., Laryea, M.M., Onumah, J.M. and Asamoah, M.E. (2020), "Intellectual capital and asset quality in an emerging banking market", Asian Journal of Accounting Research, Vol. 6 No. 1, pp. 55-68, doi: 10.1108/AJAR-05-2020-0034.

Bailey, D. and Katz, J.N. (2011), "Implementing panel-corrected standard errors in R: the PCSE package", Journal of Statistical Software, Code Snippets, Vol. 42 No. 1, pp. 1-11.

Barney, J. (1991), "Firm resources and sustained competitive advantage", Journal of Management, Vol. 17 No. 1, pp. 99-120.

Blundell, R. and Bond, S. (1998), "Initial conditions and moment restrictions in dynamic panel data models", Journal of Econometrics, Vol. 87 No. 1, pp. 115-143.

Boone, C. and Hendriks, W. (2009), "Top management team diversity and firm performance: moderators of functional background and locus of control diversity", Management Science, Vol. 55 No. 2, pp. 165-180.

Cerbioni, F. and Parbonetti, A. (2007), "Exploring the effects of corporate governance on intellectual capital disclosure: an analysis of European biotechnology companies", European Accounting Review, Vol. 16 No. 4, pp. 791-826.

Chen, F.-C., Liu, Z.-J. and Kweh, Q.L. (2014), "Intellectual capital and productivity of Malaysian general insurers", Economic Modelling, Vol. 36, pp. 413-420.

Daryaee, A., Pakdel, A., Easapour, K. and Khalaflu, M.M. (2011), "Intellectual Capital, corporate value and corporate governance (evidence from Tehran stock exchange (TSE)", Australian Journal of Basic and Applied Sciences, Vol. 5 No. 2, pp. 821-826.

Duho, K.C.T. (2020), "Intellectual capital and technical efficiency of banks in an emerging market: a slack-based measure", Journal of Economic Studies, Vol. 47 No. 7, pp. 1711-1732, doi: 10.1108/ JES-06-2019-0295.

Duru, A., Iyengar, R.J. and Zampelli, E.M. (2016), "The dynamic relationship between CEO duality and firm performance: the moderating role of board independence", Journal of Business Research, Vol. 69 No. 10, pp. 4269-4277.

El-Bannany, M. (2008), "A study of determinants of intellectual capital performance in banks: the UK case", Journal of Intellectual Capital, Vol. 9 No. 3, pp. 487-498.

Fama, E.F. and Jensen, M.C. (1983), "Separation of ownership and control", Journal of Law and Economics, Vol. 26, June, pp. 301-325. 
Goebel, V. (2015), "Estimating a measure of intellectual capital value to test its determinants", Journal of Intellectual Capital, Vol. 16 No. 1, pp. 101-120.

Goh, P.C. (2005), "Intellectual capital performance of commercial banks in Malaysia", Journal of Intellectual Capital, Vol. 6 No. 3, pp. 385-396.

Gujarati, D. and Porter, D. (2003), "Multicollinearity: what happens if the regressors are correlated", Basic Econometrics, p. 363.

Habib, A. (2015), "The new Chinese accounting standards and audit report lag", International Journal of Auditing, Vol. 19 No. 1, pp. 1-14.

Hermalin, B.E. and Weisbach, M.S. (2003), "Boards of directors as an endogenously determined institution: a survey of the economic literature", FRB New York - Economic Policy Review, Vol. 9 No. 1, pp. 7-26.

Hidalgo, R.L., Garcí-Meca, E. and Martínez, I. (2011), "Corporate governance and intellectual capital disclosure”, Journal of Business Ethics, Vol. 100 No. 3, pp. 483-495.

John, K. and Senbet, L.W. (1998), "Corporate governance and board effectiveness", Journal of Banking and Finance, Vol. 22 No. 4, pp. 371-403.

Joshi, M., Cahill, D. and Sidhu, J. (2010), "Intellectual capital performance in the banking sector: an assessment of Australian owned banks", Journal of Human Resource Costing and Accounting, Vol. 14 No. 2, pp. 151-170.

Kalim, R. and Lodhi, S.A. (2002), "The knowledge based economy: trends and implications for Pakistan”, Pakistan Development Review, Vol. 41 No. 4, pp. 787-804.

Kamath, G.B. (2008), "Intellectual capital and corporate performance in Indian pharmaceutical industry", Journal of Intellectual Capital, Vol. 9 No. 4, pp. 684-704.

Kaplan, R.S. and Norton, D.P. (2004), Strategy Maps: Converting Intangible Assets into Tangible Outcomes, Harvard Business School Press, Harvard.

Kennedy, P. (2008), A Guide to Econometrics, 6th ed., Blackwell Publishing, Oxford.

Kusi, A.B., Gyeke-Dako, A., Agbloyor, E.K. and Darku, A.B.( (2018), "Does corporate governance structures promote shareholders or stakeholders value maximization? Evidence from African banks", Corporate Governance: The International Journal of Business in Society, Vol. 18 No. 2, pp. 270-288.

Kyereboah-Coleman, A. (2006), "Corporate board diversity and performance of microfinance institutions: the effect of gender", Studies in Economics and Econometrics Vol. 30 No. 3, pp. 19-33.

Kyereboah-Coleman, A. and Biekpe, N. (2006), "The relationship between board size, board composition, CEO duality and firm performance: experience from Ghana", Corporate Ownership and Control, Vol. 4 No. 2, pp. 114-122.

Li, J., Pike, R. and Haniffa, R. (2008), "Intellectual capital disclosure and corporate governance structure in UK firms", Accounting and Business Research, Vol. 38 No. 2, pp. 137-159.

Li, J., Mangena, M. and Pike, R. (2012), "The effect of audit committee characteristics on intellectual capital disclosure”, Accounting and Business Research, Vol. 44 No. 2, pp. 98-110.

Makki, M.A.M. and Lodhi, S.A. (2009), "Impact of intellectual capital on return on investment in Pakistani corporate sector", Australian Journal of Basic and Applied Sciences, Vol. 3 No. 3, pp. 2995-3007.

Makki, M.A.M., Lodhi, S.A. and Rahman, R. (2008), "Intellectual capital performance of Pakistani listed corporate sector", International Journal of Business and Management, Vol. 3 No. 10, pp. 45-51.

Mannix, E. and Neale, M. (2005), "What differences make a difference? The promise and reality of diverse teams in organizations", Psychological Science in the Public Interest, Vol. 6 No. 2, pp. 31-55. 
AJEB

7,1

Marr, B., Gray, D. and Schiuma, G. (2004), "Measuring intellectual capital - what, why, and how?”, in Bourne, M. (Ed.), Handbook of Performance Measurement, Gee, London.

Mohamad-Nor, M.N., Shafie, R. and Wan-Hussin, W.N. (2010), "Corporate governance and audit report lag in Malaysia", Asian Academy of Management Journal of Accounting and Finance, Vol. 6 No. 2, pp. 57-84.

Mujtaba, N. and Williams, A. (2011), "Corporate governance and board composition: a comparison of GCC boards with UK, European and US boards", Report issued by corporate governance consultants, Manama, Bahrain.

Naimi, M., Nor, M., Rohami, S. and Wan-Hussin, W.N. (2010), "Corporate governance and audit report lag in Malaysia", Asian Academy of Management Journal of Accounting and Finance, Vol. 6 No. 2.

Nkundabanyanga, S.K. (2016), "Board governance, intellectual capital and firm performance Importance of multiplicative effects", Journal of Economic and Administrative Sciences, Vol. 32 No. 1, pp. 20-45.

Owusu, G.M., Saat, N.A.M., Suppiah, S.D.K. and Siong, H.L. (2017), "IFRS adoption, institutional quality and foreign direct investment inflows: a dynamic panel analysis", Asian Journal of Business and Accounting, Vol. 10 No. 2, pp. 43-75.

Ozkan, N., Cakan, S. and Kayacan, M. (2017), "Intellectual capital and financial performance: a study of the Turkish banking sector", Borsa Istanbul Review, Vol. 17 No. 3, pp. 190-198.

Pearce, J.A. and Zahra, S.A. (1992), "Board composition from a strategic contingency perspective", Journal of Management Studies, Vol. 29 No. 4, pp. 411-438.

Pfeffer, J. (1972), "Size and composition of corporate boards of directors", Administrative Science Quarterly, Vol. 17 No. 2, pp. 218-229.

Pulic, A. (2004), "Intellectual capital: does it create or destroy value? Measuring intangible assets - the state of the art", Journal of Business Performance, Vol. 8 No. 3, pp. 62-68.

Pulic, A. (2008), The Principles of Intellectual Capital Efficiency - a Brief Description, Croatian Intellectual Capital Center, Zagreb.

Swartz, N.P. and Firer, S. (2005), "Board structure and intellectual capital performance in South Africa”, Meditari Accountancy Research, Vol. 13 No. 2, pp. 145-166.

Valverde, S.C. and Fernaindez, F.R. (2017), "The determinants of bank margins in European banking”, Journal of Banking and Finance, Vol. 31 No. 7, pp. 2043-2063.

Wagiciengo, M.M. and Belal, A.R. (2012), "Intellectual capital disclosures by South African companies: a longitudinal investigation", Advances in Accounting, Incorporating Advances in International Accounting, Vol. 28 No. 1, pp. 111-119.

Weir, C. and Laing, D. (2000), "The performance-governance relationship: the effects of Cadbury compliance on UK quoted companies", Journal of Management and Governance, Vol. 4, pp. 265-281.

Wernerfelt, B. (1984), “A resource-based view of the firm”, Strategic Management Journal, Vol. 5 No. 2, pp. 171-180.

Williams, S.M. (2000), "Association between gender and colour diversity of board structure on the intellectual capital performance of publicly listed companies from and emerging economy: evidence from South Africa”, Working Paper, University of Calgary, Canada.

Williams, R.J., Fadil, P.A. and Armstrong, R.W. (2005), "Top management team tenure and corporate illegal activity: the moderating influence of board size", Journal of Managerial Issues, Vol. 17, pp. 479-493.

Wintoki, M.B., Linck, J.S. and Netter, J.M. (2012), "Endogeneity and the dynamics of internal corporate governance", Journal of Financial Economics, Vol. 105 No. 3, pp. 581-606.

Wooldridge, J.M. (2003), "Cluster-sample methods in applied econometrics", The American Economic Review, Vol. 93 No. 2, pp. 133-138. 
Yaacob, N.M. and Che-Ahmad, A. (2012), "Adoption of FRS 138 and audit delay in Malaysia", International Journal of Economics and Finance, Vol. 4 No. 1, p. 167.

Yatim, P., Kent, P. and Clarkson, P. (2006), "Governance structures, ethnicity, and audit fees of Malaysian listed firms”, Managerial Auditing Journal, Vol. 21 No. 7, pp. 757-782.

Youndt, M.A., Subramaniam, M. and Snell, S.A. (2004), "Intellectual capital profiles: an examination of investments and returns”, Journal of Management Studies, Vol. 41 No. 2, pp. 335-361.

Board

structures and intellectual capital

\section{Further reading}

García-Meca, E. and Martínez, I. (2005), "Assessing the quality of disclosure on intangibles in the Spanish capital market”, Business Review, Vol. 17 No. 4, pp. 305-313.

Joshi, M., Cahill, D. and Sidhu, J. (2013), "Intellectual capital and financial performance: an evaluation of the Australian financial sector", Journal of Intellectual Capital, Vol. 14 No. 2, pp. 264-285.

Nkundabanyanga, S.K., Ntayi, J.M., Ahiauzu, A. and Sejjaaka, S.K. (2014), "Intellectual capital in Ugandan service firms as mediator of board governance and firm performance", African Journal of Economic and Management Studies, Vol. 5 No. 3, pp. 300-340.

Waweru, N. (2014), "Determinants of quality corporate governance in Sub-Saharan Africa: evidence from Kenya and South Africa”, Managerial Auditing Journal, Vol. 29 No. 5, pp. 455-485.

\section{Corresponding author}

Nicholas Asare can be contacted at: nicholas.asare@knust.edu.gh 


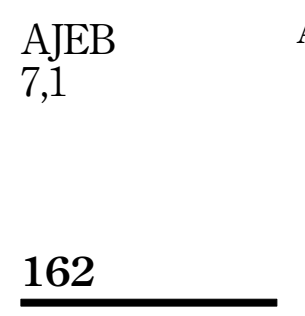

Appendix 1

AJEB

162
Table A1.

List of countries in

Africa by regions

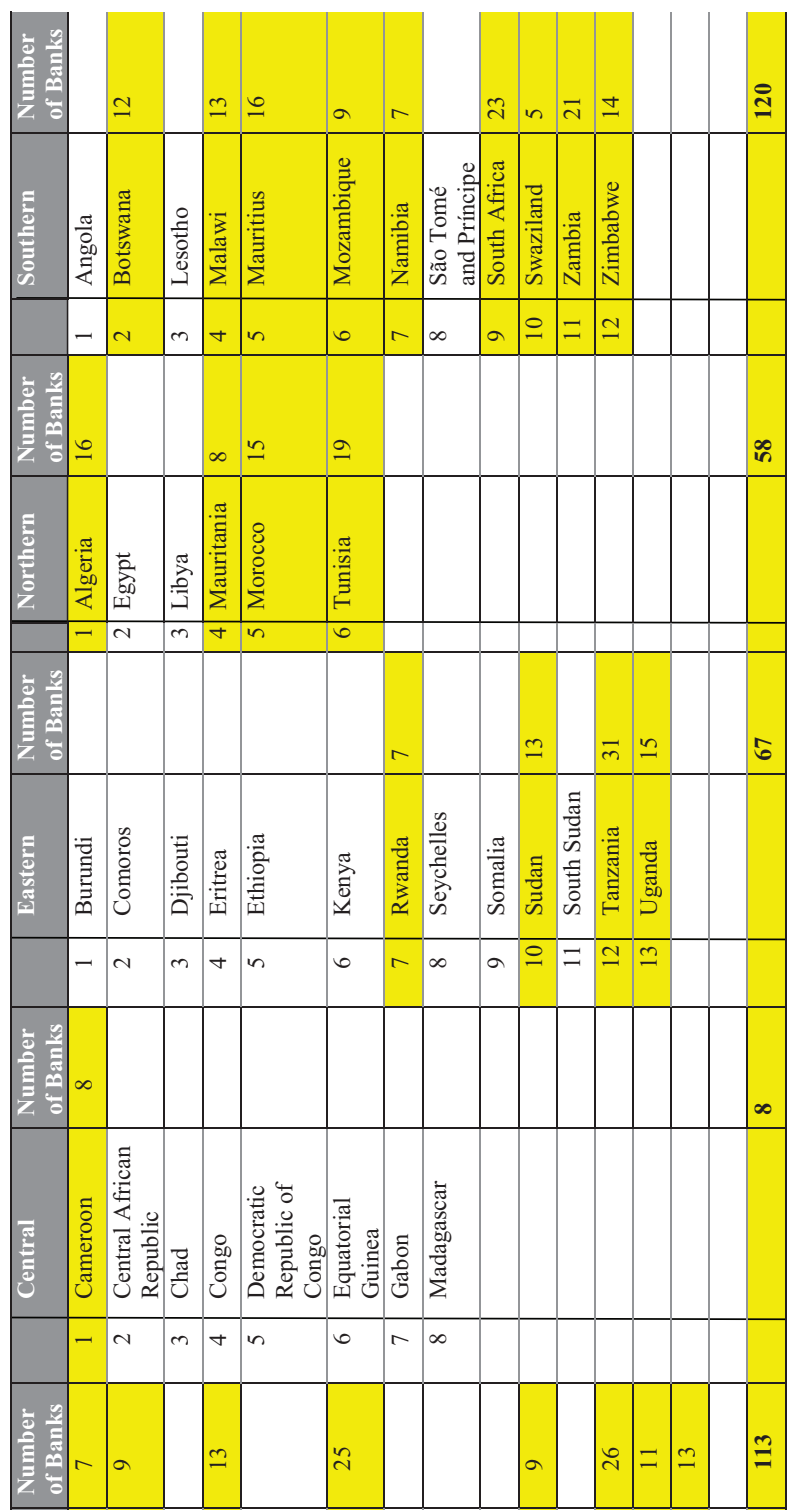

更

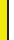

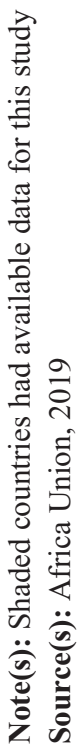




\begin{tabular}{lcc}
\hline Variable & VIF & $1 / \mathrm{VIF}$ \\
\hline BODSIZE & 1.1900 & 0.8388 \\
BODIND & 1.5900 & 0.6290 \\
BODGEN & 1.8000 & 0.5554 \\
BSIZE & 1.5700 & 0.6373 \\
CRL5 & 1.7900 & 0.5591 \\
GDPpcg & 1.3800 & 0.7244 \\
Mean VIF & 1.5500 &
\end{tabular}

Note(s): $B O D S I Z E$ is the board size; BODIND is board independence BODGEN is board gender diversity; $B S I Z E$ is bank size; CRL5 is 5 bank loan concentration ratio; GDPpcg is gross domestic product per capita growth rate

Source(s): Bank Scope and authors' computations, 2019

\section{Appendix 3}

\section{Intellectual capital}

The computation of VAIC is simplified as follows (Pulic, 2004, 2008):

$$
\mathrm{VA}=\mathrm{OUT}-\mathrm{IN}
$$

where OUT is the total revenues of a bank consisting of interest incomes, fees and commission incomes; IN denotes bank costs of operations comprising interest, finance and administration expenses (excluding personnel expenses, treated as investments but not costs). The equation for computing Human capital efficiency (HCE) is specified by

$$
\mathrm{HCE}=\frac{\mathrm{VA}}{\mathrm{HC}}
$$

where VA is value added described in 1 and $\mathrm{HC}$ is the wages and salaries constituting total remuneration. The calculation for Structural Capital (SC) of a bank is as follows:

$$
\mathrm{SC}=\mathrm{VA}-\mathrm{HC}
$$

VA and HC are as per equations (A1) and (A3). The equation specified in equation (A4) is Structural Capital efficiency (SCE):

$$
\mathrm{SCE}=\frac{\mathrm{SC}}{\mathrm{VA}}
$$

The equation on the efficiency of the capital employed efficiency (CEE) is computed as follows:

$$
\mathrm{CEE}=\frac{\mathrm{VA}}{\mathrm{CE}}
$$

where $\mathrm{CE}$ is the bank's net book value of the net assets.

Largely, the value formation efficiency (i.e. Value added intellectual capital efficiency - VAIC) is the sum of all value making efficiencies as specified in equation (A7); whereas the IC efficiency is as specified in equation (A6).

$$
\begin{gathered}
\mathrm{ICE}=\mathrm{HCE}+\mathrm{SCE} \\
\mathrm{VAIC}^{\mathrm{TM}}=\mathrm{ICE}+\mathrm{CEE}
\end{gathered}
$$

